\title{
Kegiatan "Rumah Belajar" Sebagai Media Menganalisis Perilaku Keluarga dengan Risiko Kejadian Balita Stunting
}

\section{“Rumah Belajar" Activities as a Media for Analyzing Family Behavior with Toddler Stunting Risk}

\author{
NLP Yunianti Suntari $C^{1}$, I Ketut Gama ${ }^{2}$ \\ Jurusan Keperawatan, Politeknik Kesehatan Denpasar, Indonesia
}

\section{ARTICLE INFO}

\section{Article history:}

Received date

19 Dec 2019

Revised date

27 Feb 2020

Accepted date

15 Apr 2020

\section{Keywords:}

Family behavior;

"Rumah Belajar"

activity;

Stunting.

\section{Kata kunci:}

Perilaku keluarga;

Kegiatan "Rumah

Belajar";

Stunting.

\author{
ABSTRACT/ ABSTRAK
}

The rate of stunting or dwarf or acute malnutrition in children aged 1000 days in Indonesia is stagnant, which is around 37\% of births from 2007 to 2013 (World Bank Report: Aiming High and Riskesdas, 2013). Children who are stunted will be more susceptible to illness and experience a decline in cognitive abilities that impact on the child's economic abilities in the future. Family development and empowerment is part of sensitive nutrition interventions. In carrying out its function role, the family has views and beliefs which will certainly affect the way the family takes care of children. This family paradigm is a basic belief held by the family, and guides actions in caring for and caring for their children. The "Rumah Belajar" activity guide for researchers developed into a joint study guide that families can do as a medium to analyze risky behavior in families with stunting toddlers in Singakerta Village, Ubud. This research uses quasi-experiment design. 66 families as a control group and 72 families as a treatment group. Samples are taken randomly from the number of banjar/posyandu available. Test the difference in the average of two sample pairs, before and after the "Rumah Belajar" activity in the treatment group. The results of the correlation before and after the "Rumah Belajar" in the treatment group showed a .866 figure with a probability value (sig) of .000 . This means that family risk behavior is significantly related. Based on the comparison of the probability value (sig) $.000<0.05$, then $\mathrm{Ha}$ is accepted that there are significant differences in family risk behavior before and after the "Rumah Belajar" activity.

Angka stunting atau kerdil atau kurang gizi akut pada anak berusia 1000 hari di Indonesia stagnan tinggi, yaitu di angka sekitar 37\% dari kelahiran sejak 2007 sampai dengan tahun 2013. Anak yang stunting akan lebih rentan terkena penyakit serta mengalami penurunan kemampuan kognitif yang berimbas pada kemampuan ekonomi anak tersebut di masa depan. Pembangunan dan pemberdayaan keluarga merupakan bagian dari intervensi gizi sensitif. Dalam melaksanakan peran fungsinya, keluarga memiliki pandangan dan keyakinan yang pastinya akan mempengaruhi cara keluarga dalam pengasuhan anak. Paradigma keluarga ini merupakan keyakinan dasar yang dimiliki keluarga, dan membimbing tindakan dalam mengasuh dan merawat anak-anak mereka. Panduan kegiatan "Rumah belajar" peneliti kembangkan menjadi suatu pedoman belajar bersama yang dapat dilakukan keluarga sebagai media menganalisis perilaku berisiko pada keluarga dengan kejadian balita stunting di Desa Singakerta Ubud. Penelitian ini menggunakan desain quasi-eksperiment. 66 keluarga sebagai kelompok kontrol dan 72 keluarga sebagai kelompok perlakuan. Sampel diambil secara acak dari jumlah banjar/posyandu yang ada. Uji perbedaan rata-rata dua sampel berpasangan, sebelum dan setelah kegiatan "Rumah Belajar" pada kelompok perlakuan. Dilihat hasil korelasi sebelum dan setelah kegiatan "Rumah Belajar" pada kelompok perlakuan, menunjukkan angka .866 dengan nilai probabilitas (sig) .000 . Hal ini menyatakan bahwa perilaku berisiko keluarga berhubungan secara nyata. Berdasarkan perbandingan nilai probabilitas (sig) $.000<0.05$, maka Ha diterima. Ada perbedaan yang nyata dan signifikan pada perilaku berisiko keluarga sebelum dan setelah kegiatan "Rumah Belajar".

Corresponding Author:

NLP Yunianti Suntari C

Jurusan Keperawatan, Politeknik Kesehatan Denpasar, Indonesia

Email: yuni.suntari@yahoo.com 


\section{PENDAHULUAN}

Siklus kehidupan dimulai sejak dalam kandungan, masa bayi, balita, anak, remaja, dewasa dan usia lanjut. Pada siklus tersebut, bisa muncul beragam masalah kesehatan. Salah satu masalah yang bisa muncul pada awal rentang siklus tersebut adalah masalah gizi. Kondisi gizi merupakan salah satu indikator penting dalam kualitas hidup seseorang, terutama anak-anak. Kualitas hidup seorang anak menjamin pertumbuhan dan perkembangannya baik fisik maupun mental. Juga untuk meningkatkan kekebalan tubuh, sehingga mereka terlindungi dari penyakit. Masalah gizi yang masih terjadi pada saat ini adalah malnutrisi, berlebih ataupun kurang, dan stunting.

Stunting adalah sebuah kondisi dimana tinggi badan seseorang yang lebih pendek dibanding tinggi badan orang lain pada umumnya (yang seusia). Stunting berdampak bagi kesehatan dalam jangka pendek dan jangka panjang. Jangka pendek dapat dilihat dari gangguan perkembangan pada otak, gangguan kecerdasan, gangguan pertumbuhan, dan juga gangguan pada metabolisme tubuh. Jangka panjangnya meliputi penurunan kemampuan kognitif dan prestasi belajar, mudah terserang penyakit akibat kelemahan system imun, anak memiliki resiko tinggi penyakit diabetes, obesitas, penyakit jantung, pembuluh darah, kanker, stroke, serta disabilitas pada usia lanjut. (Kemendesa PDTT, 2017).

Pada tahun 2016, prevalensi kejadian stunting pada baduta ( $0-23$ bulan) di Indonesia yaitu baduta sangat pendek $(8,4 \%)$ dan baduta pendek (14,7\%) (Direktorat Gizi Masyarakat, 2017). Persentase kejadian stunting pada baduta (0-23 bulan) di Indonesia mengalami penurunan pada tahun 2016 menjadi sangat pendek sebesar $(7,1 \%)$ dan balita pendek $(14,6 \%)$ (Kementerian Kesehatan RI, 2017). Tahun 2017 prevalensi kejadian stunting pada baduta (0-23 bulan) kembali menurun menjadi sangat pendek $(6,9 \%)$ dan pendek $(13,2 \%)$. Provinsi dengan persentase tertinggi baduta (0-23 bulan) sangat pendek dan pendek pada tahun 2017 adalah Kalimantan Tengah $(30,4 \%)$, sedangkan provinsi dengan persentase terendah adalah Bali (13,6\%) (Sekretariat Wakil Presiden RI, 2017).

Kabupaten di Bali yang memiliki masalah stunting di atas target nasional (kurang dari 20\%) adalah Kabupaten Buleleng, Jembrana, Karangasem, Gianyar, dan Bangli. Data PSG Tahun 2017 menunjukkan bahwa Kecamatan Ubud menyumbang stunting dengan prevalensi tertinggi di Gianyar yaitu sebesar 5,4\% untuk kategori sangat pendek dan 23,2\% untuk kategori pendek (Direktorat Gizi Masyarakat, 2017). Salah satu Desa Lokasi Fokus (Lokus) Stunting di Kecamatan Ubud ialah Desa Singakerta yang merupakan wilayah kerja Puskesmas Ubud II (Dinas Kesehatan Bali, 2018). Hasil PSG 2017 menunjukkan sebanyak 70 balita mengalami stunting di Desa Singakerta (Direktorat Gizi Masyarakat, 2017).

Awalnya stunting sering dikaitkan dengan status ekonomi yang rendah. Jika hanya karena status ekonomi rendah, kejadian stunting pastilah hanya terjadi di daerah dengan populasi miskin, di negara miskin dan negara berkembang. Akan tetapi fakta di lapangan, menunjukkan fenomena menarik. Stunting bisa terjadi pada keluarga mampu. Gizi buruk bukanlah situasi yang mendadak terjadi. Ada suatu peristiwa melatarbelakangi. Permasalahan ini tidak hanya selesai dengan pemberian bantuan beras atau makanan lain, ataupun makanan tambahan. Tapi juga akses terhadap nutrisi, pengetahuan, sikap dan perilaku.

Pemerintah Indonesia membuat kerangka intervensi stunting yang terbagi menjadi dua yaitu intervensi gizi spesifik dan intervensi gizi sensitif. Intervensi gizi spesifik diberikan pada ibu dari masa kehamilan, melahirkan dan menyusui. Juga pada batita sampai berusia 24 bulan. Sedangkan untuk kerangka yang kedua yaitu intervensi gizi sensitif dilakukan melalui pembangunan sektor pendukung kesehatan, seperti akses air bersih, sanitasi, bahan pangan, layanan kesehatan dan KB, Jaminan Kesehatan Nasional (JKN), Jaminan Persalinan Universal (Jampersal), pendidikan pengasuhan pada orangtua, pendidikan anak usia dini (PAUD), pendidikan gizi masyarakat, meningkatkan ketahanan pangan dan gizi, edukasi kesehatan, seksual dan reproduksi (Sekretariat Wakil Presiden RI, 2017).

Pemberdayaan perempuan dalam keluarga, melalui peningkatan pendidikan dan pengetahuan gizi dan kesehatan, adalah salah satu cara untuk menurunkan risiko kejadian stunting. Karena perempuan adalah pengasuh utama dalam keluarga (Rosha, 2016).

Anak yang lahir sehat dan tumbuh dengan baik, di lingkungan keluarga yang baik, akan menjadi generasi yang dapat menunjang keberhasilan pembangunan suatu bangsa. Lebih lanjut, Rosha (2016) menyampaikan, pembangunan dan pemberdayaan keluarga merupakan bagian dari intervensi gizi sensitif. Ini menjadi hal yang sangat krusial, mengingat anak dibesarkan di tengah keluarga. Dalam 
melaksanakan peran fungsinya, keluarga memiliki pandangan dan keyakinan yang pastinya akan mempengaruhi cara keluarga dalam pengasuhan anak.

Situasi ini yang melatarbelakangi pemikiran melibatkan upaya dan peran keluarga dalam jangka panjang untuk menurunkan stunting dan terutama dampak ke depannya. Penelitian ini berfokus pada salah satu intervensi gizi sensitif, yaitu pendidikan pengasuhan pada orang tua. Bagaimana sebuah kegiatan belajar pada keluarga dapat memperbaiki cara keluarga dalam mengasuh balita stunting. Kegiatan belajar dalam studi ini diberi nama "Rumah Belajar". Pendidikan pengasuhan bertujuan untuk meningkatkan pemahaman orang tua tentang pentingnya menerapkan pola asuh yang baik di rumah (Kementerian Sosial, 2018), dalam memenuhi kebutuhan anak, baik memenuhi kebutuhan gizi untuk bertumbuh, juga untuk perkembangannya.

Selama kegiatan pengasuhan, orang tua berinteraksi dengan anak, memenuhi kebutuhannya, menanamkan nilai, sikap dan perilaku. Termasuk didalamnya perilaku hidup sehat bebas stunting, dan orang tua menjadi sumber belajar bagi anak.

Sebuah perilaku dibangun dari proses belajar. Perilaku keluarga dalam mengatasi dan mencegah stunting dapat dibangun dalam proses belajar. Perkembangan perilaku dihasilkan oleh respon seseorang terhadap rangsangan yang diperkuat dengan umpan balik positif atau negative terhadap perilaku yang diinginkan, dikenal dengan teori belajar behaviorisme, menurut Gagne dan Berliner dalam Rifa'i (2011). Lebih lanjut dijelaskan, penerapan teori ini adalah perubahan perilaku terjadi karena rangsangan model perilaku yang menjadi contoh. Rangsangan ini hadir secara berulang. Kemudian individu mendapat penguatan sebagai dampak dari perilaku baru.

Pemahaman teori ini menjadi acuan peneliti dalam mengemas kegiatan "Rumah Belajar" menjadi prinsip yang diterapkan dalam kegiatan "Rumah Belajar", yaitu 1) Modelling: adanya contoh tingkah laku yang diharapkan terjadi; 2) Repetition: pengulangan tingkah laku, dan; 3) Reinforcment: memberi penguatan pada tingkah laku tersebut.

Studi ini bertujuan menganalis perbedaan perilaku berisiko pada keluarga dengan kejadian balita stunting sebelum dan setelah kegiatan "Rumah Belajar".

\section{METODE}

Penelitian ini menggunakan desain quasieksperiment. Melihat perbedaan perilaku berisiko pada keluarga dengan risiko kejadian balita stunting sebelum dan setelah kegiatan "Rumah Keluarga". Pengamatan dilakukan pada dua kelompok, kelompok perlakuan dan kelompok control, yang berasal dari 8 banjar/posyandu dari 14 banjar/posyandu. Populasi pada penelitian ini adalah keluarga dengan balita di desa Singakerta. Total populasi berjumlah 140 keluarga. 66 keluarga sebagai kelompok kontrol dan 72 keluarga sebagai kelompok perlakuan. Sampel diambil secara acak dari jumlah banjar/posyandu yang ada. Dengan kriteria bersedia menjadi responden. Sampel dikeluarkan (kriteria eksklusi) jika tidak dapat mengikuti intervensi sesuai dengan program yang telah direncanakan, dan tidak bersedia berpartisipasi.

Penelitian ini telah melewati kaji etik dan memperoleh Persetujuan Etik dengan Nomor LB.02.03/EA/KEPK/0401/2019 oleh Komisi Etik Penelitian Kesehatan (KEPK) Politeknik Kesehatan Denpasar.

Teknik pengumpulan data diperoleh dengan pengamatan dan wawancara, untuk data perilaku berisiko pada keluarga dengan kejadian balita stunting (sebelum dan setelah dilakukan pelatihan dan pendampingan dalam kegiatan "Rumah Belajar").

Ada dua kelompok, perlakuan dan kontrol. Kedua kelompok diberikan materi belajar mengenai stunting: mengenal stunting, mengenal dan menyiapkan makanan bergizi pada balita dan bagaimana mendisiplinkan balita. Kelompok kontrol dibagikan materi dalam bentuk pamflet yang bisa dibaca dan dipelajari sendiri. Kelompok perlakuan didampingi dan difasilitasi mengikuti kegiatan "Rumah Belajar". Kegiatan "Rumah Belajar" pada penelitian ini menyiapkan kebutuhan materi yang diperlukan oleh keluarga dengan balita risiko stunting, Inti dari materi adalah mengenal stunting, mengenal dan menyiapkan makanan bergizi pada balita, mendisiplinkan balita.

Mekanisme di setiap pertemuan kegiatan "Rumah Belajar", sebagai berikut:

Pada kelompok perlakuan dikenakan dua kali pertemuan setiap minggu, dengan agenda:

1) Fasilitator membuka kegiatan dan mengajukan topik pertemuan, dengan cara melakukan brain stroming pada peserta, mendapatkan permasalahan yang sedang dihadapi keluarga.

2) Diskusi dipandu fasilitator:
a. Peserta bertanya seputar topik 
b. Peserta menceritakan pengalaman seputar topik

c. Fasilitator mengarahkan agar pembicaraan tidak keluar dari topik. Dengan berpatokan pada prinsip "Rumah Belajar" Modelling (memberikan contoh), Repetition (melakukan berulangulang) dan Reinforcement (memberi penguatan hanya pada perilaku positif).

d. Peserta menyampaikan komitmen yang akan dilakukan sesuai dengan topik

e. Fasilitator menyimpulkan, memandu perencanaan kegiatan/pertemuan berikutnya dan menutup kegiatan.

Pada setiap kegiatan peserta sangat antusias dan saling menguatkan. Ketika seorang peserta mendapatkan masalah, peserta yang lain akan memberi masukan apa yang mereka lakukan saat mendapatkan masalah yang sama. Fasilitator mendengarkan, mengarahkan dan menegaskan, apa tindakan yang tepat untuk mengatasi masalah tersebut. Sehingga setiap peserta mendapatkan pengetahuan dan pemahaman baru sesuai kebutuhan mereka. Di akhir sesi, setiap peserta menyampaikan apa komitmen mereka dalam mengatasi masalah tersebut.

Teknik analisa data yang dipakai adalah analisa deskriptif (Setiadi, 2013). Analisa univariat untuk mengidentifikasi perilaku berisiko keluarga dengan kejadian balita stunting sebelum dan setelah kegiatan "Rumah Belajar". Uji analisa beda rata-rata dua sampel untuk menganalis perbedaan perilaku berisiko pada keluarga dengan kejadian balita stunting sebelum dan setelah kegiatan "Rumah Belajar" pada kelompok kontrol maupun perlakuan.

\section{HASIL}

Tabel 1. Diskripsi Perilaku Keluarga pada Kelompok Perlakuan Sebelum dan Setelah Kegiatan "Rumah Belajar"

\begin{tabular}{lccccc}
\hline & n & Min & Max & Mean & SD \\
\hline $\begin{array}{l}\text { Pre } \\
\text { Perlakuan }\end{array}$ & 72 & 42,00 & 70,00 & 58,36 & 5,69 \\
$\begin{array}{l}\text { Post } \\
\text { Perlakuan }\end{array}$ & 72 & 45,00 & 72,00 & 61,87 & 5,34 \\
\hline
\end{tabular}

Berdasarkan tabel 1 dapat dilihat perilaku berisiko keluarga, pada kelompok perlakuan, sebelum mendapatkan kegiatan "Rumah Belajar", dengan rentang skor $42 \mathrm{~s} / \mathrm{d}$ 70, mean 58,36 dan SD 5,69. Dan dengan rentang skor 45 s/d 72, mean 61,87 dan SD 5,34 setelah mengikuti kegiatan "Rumah Belajar". Terjadi peningkatan mean 3,51. Maknanya ada perubahan peningkatan perilaku keluarga setelah mengikuti kegiatan "Rumah Belajar".

\section{Tabel 2. Deskripsi Perilaku Keluarga pada Kelompok Kontrol Sebelum dan Setelah Kegiatan}

\begin{tabular}{llllrl}
\hline & n & Min & Max & Mean & SD \\
\hline Pre Kontrol & 66 & 47,00 & 69,00 & 58,34 & 5,43 \\
Post Kontrol & 66 & 48,00 & 69,00 & 58,59 & 5,43 \\
\hline
\end{tabular}

Dari tabel 2 dapat dilihat perilaku keluarga, pada kelompok kontrol, sebelum kegiatan belajar dengan pamflet dengan rentang skor 47 s/d 69, mean 58,34 dan SD 5,43. Setelah kegiatan belajar dengan pamflet, dengan rentang skor $48 \mathrm{~s} / \mathrm{d}$ 69, mean 58,59 dan SD 5,43. Menunjukkan tidak adanya perubahan perilaku sebelum maupun setelah kegiatan belajar dengan penggunaan media pamflet ini.

\begin{tabular}{|c|c|c|c|c|}
\hline & \multicolumn{2}{|c|}{$\begin{array}{l}\text { Deskripsi Korela } \\
\text { Sebelum dan } \\
\text { "Rumah Belajar" }\end{array}$} & $\begin{array}{l}\text { si Kedua } \\
\text { Setelah }\end{array}$ & Kegiatan \\
\hline & & $\mathbf{n}$ & Correlation & Sig. \\
\hline Pair 1 & $\begin{array}{l}\text { Pre } \\
\text { Perlakuan } \\
\text { \& Post } \\
\text { Perlakuan }\end{array}$ & 72 & ,866 & ,000 \\
\hline Pair 2 & $\begin{array}{l}\text { Pre } \\
\text { Kontrol \& } \\
\text { Post } \\
\text { Kontrol }\end{array}$ & 66 & ,988 & ,000 \\
\hline
\end{tabular}

Tabel 4. Analisis Paired Sample $t$ Test Kedua Kelompok Sebelum dan Setelah Kegiatan "Rumah Belajar"

\begin{tabular}{cccc}
\hline Pair & Mean & $\mathbf{t}$ & $\begin{array}{c}\text { Sig.(2- } \\
\text { tailed) }\end{array}$ \\
\hline $\begin{array}{cccc}\text { Pre-Post } \\
\text { Perlakuan }\end{array}$ & $-3,51389$ & $-10,343$ &, 000 \\
\hline $\begin{array}{c}\text { Pre-Post } \\
\text { Kontrol }\end{array}$ & $-0,24242$ & $-2,338$ &, 202 \\
\hline
\end{tabular}

\section{Studi Komparasi pada Kelompok Perlakuan}

Menganalisa tabel-tabel di atas, pada uji perbedaan rata-rata dua sampel berpasangan, sebelum dan setelah kegiatan "Rumah Belajar" pada kelompok perlakuan. Pertama dapat dilihat hasil korelasi antara variabel sebelum dan setelah kegiatan "Rumah Belajar" pada kelompok perlakuan, menunjukkan angka ,866 dengan nilai probabilitas (sig) ,000. Hal ini menyatakan bahwa korelasi antara sebelum dan setelah kegiatan "Rumah Belajar" berhubungan secara nyata, karena nilai probabilitas <0,05. Berdasarkan perbandingan nilai probabilitas (sig), $000<0,05$, maka Ho ditolak. Kedua rata-rata 
populasi tidak sama. Ada perbedaan yang nyata dan signifikan pada perilaku berisiko keluarga sebelum dan setelah kegiatan "Rumah Belajar".

\section{Studi Komparasi pada Kelompok Kontrol}

Mencermati kedua tabel di atas, sebelum dan setelah kegiatan pada kelompok kontrol. Dapat dilihat perbandingan nilai probabilitas (sig),202>0,05, maka Ho diterima. Kedua ratarata populasi sama. Tidak ada perbedaan yang nyata dan signifikan pada perilaku berisiko keluarga sebelum dan setelah kegiatan belajar.

Studi Komparasi pada Kelompok Perlakuan dan Kontrol Setelah Kegiatan "Rumah Belajar"

Tabel 5. Analisis Independent Sample $t$ Test pada Kedua Kelompok Setelah Kegiatan "Rumah Belajar"

\begin{tabular}{llccccc}
\hline & & $\boldsymbol{F}$ & Sig. & $\boldsymbol{t}$ & df & $\begin{array}{c}\text { Sig. (2- } \\
\text { tailed) }\end{array}$ \\
\hline Post & $\begin{array}{l}\text { Equal } \\
\text { variances } \\
\text { assumed }\end{array}$ & 015 &, 904 & 3,577 & 136 & 000 \\
\hline
\end{tabular}

Langkah awal, menguji apakah kedua kelompok memiliki varian yang sama. Uji homogenitas dapat dilihat $\mathrm{F}=0,015 \quad(p$ value $=0,904)$, karena $p$-value di atas 0,05 , maka dapat dikatakan bahwa tidak ada perbedaan varians data perilaku keluarga pada kelompok perlakuan maupun kelompok kontrol setelah kegiatan "Rumah Belajar".

Data yang homogen dilanjutkan dengan melihat equal variances assumed. Didapat bahwa nilai t hitung $=3,577$. Selanjutnya melihat nilai rata-rata kedua kelompok. Dengan Ho yang berbunyi, kedua kelompok memiliki nilai ratarata yang sama. Dilihat dari Sig. (2-tailed) 0,000, yang lebih kecil dari 0,05 , maka Ho ditolak. Kesimpulannya, dengan tingkat signifikansi 5\% didapatkan ada perbedaan rata-rata kelompok perlakuan yang mendapat kegiatan "Rumah Belajar" dengan kelompok kontrol yang mengikuti kegiatan belajar dengan media pamflet. Dan jika dibandingkan, rata-rata kelompok perlakuan lebih tinggi dibandingkan rata-rata kelompok kontrol (tabel 1 dan 2). Terlihat bahwa nilai mean perilaku pada kelompok kegiatan "Rumah Belajar" lebih tinggi $(61,87)$ daripada kelompok yang belajar hanya dengan membaca pamflet $(58,59)$.

\section{PEMBAHASAN}

Banyak hal yang bisa dicermati dari uraian data di atas. Terdapat perbedaan yang bermakna pada perilaku berisiko keluarga, pada kelompok yang mendapat pengalaman mengikuti kegiatan "Rumah Belajar". Interaksi yang dibangun pada kegiatan "Rumah Belajar", mampu menggali kemampuan para keluarga untuk memahami faktor-faktor yang dapat memicu kejadian stunting pada anak.

Probohastuti (2019) pada risetnya tentang Intervensi Gizi Sensitif, menunjukkan bahwa implementasi kebijakan intervensi gizi sensitif untuk penurunan stunting di Kabupaten Blora belum semuanya berjalan optimal. Seperti 1) peningkatan penyediaan air minum dan sanitasi; 2) peningkatan akses dan kualitas pelayanan gizi dan kesehatan; 3) peningkatan kesadaran, komitmen, praktik pengasuhan, serta gizi ibu dan anak; 4) peningkatan akses pangan bergizi. Dalam setiap upaya peningkatan terdapat program yang belum berjalan maksimal sehingga belum dapat memberikan dampak yang maksimal kepada penurunan stunting. Hal ini dikarenakan terdapat faktor penghambat yaitu kurangnya sumber daya manusia dan anggaran, penyebaran informasi belum maksimal, kurangnya dukungan dan kesadaran masyarakat, serta data yang tidak valid.

Kurangnya sumber daya, penyebaran informasi belum maksimal menjadi alasan kegiatan "Rumah Belajar" dalam penelitian ini. Bahwa keluarga, masyarakat sangat membutuhkan belajar bersama, dengan materi terkait kehidupan rumah tangga, seperti dalam wadah kegiatan "Rumah Belajar".

Kegiatan "Rumah Belajar" juga memanfaatkan penggunaan media sosial. Pada saat memanfaatkan media sosial, keluarga juga diberi edukasi, tentang laman yang baik yang dapat mengajarkan tentang pertumbuhan, pengasuhan anak, terutama terkait pemenuhan nutrisi anak. Berbicara tentang kegiatan merawat anak, mendampinginya dalam masa pertumbuhan dan perkembangan, tidak terlepas dari pola asuh yang diterapkan orang tua pada anak.

Hal lain yang dicermati Ni'mah (2015), dalam risetnya mengatakan banyak faktor yang dapat menyebabkan terjadinya stunting pada balita seperti karakteristik balita. Lebih lanjutnya dalam studinya ditemukan hubungan antara panjang badan lahir balita, riwayat ASI eksklusif, pendapatan keluarga, pendidikan ibu dan pengetahuan gizi ibu terhadap kejadian stunting pada balita. Perlunya program yang terintegrasi dan multisektoral untuk meningkatkan 
pendapatan keluarga, pendidikan ibu, pengetahuan gizi ibu dan pemberian ASI eksklusif untuk mengurangi kejadian stunting. Di sini juga dapat dilihat betapa pentingnya peranan belajar pada keluarga untuk meningkatkan pengetahuan dan membantu menangani permasalahan stunting.

Lebih lanjut Widyaningsih

menemukan adanya hubungan antara panjang badan lahir, pola asuh makan dan keragaman pangan dengan stunting. Faktor resiko kejadian stunting yang paling dominan adalah keragaman pangan. Pola asuh makan dan keragaman pangan adalah hal yang dapat dibangun dalam kegiatan belajar yang difasilitasi tenaga kesehatan.

Dari beberapa studi ini dapat dipahami bahwa keluarga dapat menggali potensi serta meningkatkan cara pengasuhan dengan mengikuti kegiatan belajar bagi keluarga. Kegiatan "Rumah Belajar" adalah kegiatan bersama kelompok belajar orang tua untuk belajar bersama tentang pengasuhan anak. Utamanya pencegahan dan penatalaksanaan stunting. Prinsip yang diterapkan dalam kegiatan "Rumah Belajar" membantu keluarga mengarahkan anak dalam hal perilaku makan yang benar. Dengan cara ini perilaku berisiko terjadinya stunting dapat ditasi.

Cara pengasuhan orang tua kepada anakanak mereka, bagaimana orang tua menerapkan pola asuh yang dipahami (Marimbi, 2010). Pada kegiatan "Rumah Belajar" keluarga dibimbing untuk menerapkan pola asuh yang positif dan bermanfaat untuk anak, membantu anak bertumbuh dan berkembang sesuai usia. Ada tiga hal pokok yang diajarkan dan dikerjakan pada kegiatan "Rumah Belajar". Pertama Modelling keluarga menjadi model atau panutan anak dalam bertingkah laku dan bersikap. Dalam banyak hal, keluarga harus menjadi model yang tepat bagi anak. Pun dalam memilih dan mengkonsumsi asupan nutrisi yang baik. Kedua Repetition, mengulang terus menerus, konsisten menjalankan serta menerapkan hal-hal yang sudah disepakati dengan anak. Sehingga nilai yang tertanam pada anak menjadi jelas baginya. Menjadi panduan yang jelas bagi anak untuk bertingkah laku. Terakhir Reinforcement yaitu langkah penguatan bagi setiap hal baik dan positif yang dilakukan anak.

Di Desa Singakerta Kecamatan Ubud Gianyar, yang menunjukkan sebagian besar masyarakat cenderung menerapkan pola asuh otoriter. Mereka tidak mengajari cara makan yang benar, kebanyakan orang tua cenderung memberi perintah pada anak-anak mereka, dan tidak ada kesempatan bagi anak untuk berargumentasi menyampaikan keinginannya. Meskipun ibu sebagai ibu rumah tangga yang mengasuh di rumah, terutama dalam hal pemberian makan biasanya pola asuh otoriter menerapkan peraturan kaku, mengatur porsi makan dan waktu makan, orang tua otoriter juga menyeleksi dengan ketat jenis makanan yang boleh dimakan oleh anaknya. Sehingga memunculkan sejumlah kebiasaan pada anak seperti terhambatnya kemampuan anak untuk mengenali rasa lapar dan kenyang karena jadwal makan yang terlalu ketat diatur oleh orang tuanya. Anak menjadi kurang antusias terhadap makanan atau kegiatan makan, dan anak juga akan lebih rewel saat mendekati waktu makan.

Pola asuh adalah kemampuan orang tua dan keluarga untuk menyediakan waktu, perhatian, kasih sayang dan dukungan terhadap anak agar dapat tumbuh dan berkembang dengan baik secara fisik, mental dan sosial (Hurlock 2013). Pengasuhan merupakan faktor yang sangat erat kaitannya dengan pertumbuhan dan perkembangan anak berusia di bawah lima tahun. Masa balita adalah masa dimana anak sangat membutuhkan suplai makanan dan gizi dalam jumlah yang memadai. Oleh karena itu, pengasuhan kesehatan dan pemberian makanan pada tahun pertama kehidupan sangat penting untuk pertumbuhan dan perkembangan anak.

Pada kegiatan "Rumah Belajar", orang tua diajak kembali untuk mengingat lagi peran sebagai orang tua. Menerapkan prinsip "Rumah Belajar" dalam pengasuhan anak-anak mereka. Juga menerapkannya dalam pengasuhan gizi pada anak balita. Sehingga perilaku berisiko terjadinya stunting dapat dihindari.

Kejadian stunting sendiri, dipengaruhi oleh beberapa faktor yaitu penyebab stunting dapat juga dikatakan sebagai suatu bentuk adaptasi fisiologis pertumbuhan atau non patologis karena penyebab utamanya adalah asupan makanan yang tidak adekuat dan respon terhadap tingginya penyakit infeksi (Hartono, 2017). Menurut (Supariasa, 2016) menyatakan faktor-faktor yang dapat mempengaruhi stunting terbagi atas dua macam faktor yaitu faktor secara langsung yakni asupan makanan, penyakit infeksi, berat badan lahir rendah dan genetik. Sedangkan faktor secara tidak langsung yakni pengetahuan tentang gizi, pendidikan orang tua, sosial ekonomi, pola asuh orang tua, distribusi makanan dan besarnya keluarga/jumlah anggota keluarga

Dalam pemberian makanan ibu membebaskan anak untuk memilih makanan namun tetap dalam pengawasan. Ibu balita dalam memberikan makanan masih banyak dipengaruhi oleh keinginan anak mereka. Jika balita tidak 
mau makan makanan keluarga dan lebih memilih makanan camilan, maka ibu menganggap hal tersebut merupakan hal biasa. Hal ini juga didukung dengan bagaimana ibu dalam memilih makanan camilan buat anak, pembelian camilan seperti makanan ringan, coklat atau krupuk dianggap dapat menggantikan posisi makanan utama karena anak akan merasa kenyang

Stunting berdampak bagi kesehatan dalam jangka pendek dan jangka panjang. Jangka pendek dapat dilihat dari gangguan perkembangan pada otak, gangguan kecerdasan, gangguan pertumbuhan, dan juga gangguan pada metabolisme tubuh. Jangka panjangnya meliputi penurunan kemampuan kognitif dan prestasi belajar, mudah terserang penyakit akibat kelemahan sistem imun, anak memiliki resiko tinggi penyakit diabetes, obesitas, penyakit jantung, pembuluh darah, kanker, stroke, serta disabilitas pada usia lanjut (Kemendesa PDTT, 2017).

Rencana Aksi Nasional Penanganan Stunting yang telah diresmikan pada tahun 2017 menekankan pada kegiatan konvergensi di tingkat Nasional, Daerah dan Desa, untuk memprioritaskan kegiatan intervensi Gizi Spesifik dan Gizi Sensitif pada 1000 Hari Pertama Kehidupan (HPK) sampai usia 6 tahun. Intervensi Gizi Spesifik terdiri dari intervensi yang ditujukan kepada ibu hamil dan anak dalam 1000 hari pertama kehidupan, kegiatan biasanya dilakukan oleh sektor kesehatan, intervensi spesifik bersifat jangka pendek dan hasilnya dapat dicatat dalam waktu relatif pendek. Intervensi Gizi Sensitif terdiri dari intervensi yang ditujukan melalui berbagai kegiatan pembangunan di luar sektor kesehatan, sasarannya adalah masyarakat umum atau tidak khusus untuk sasaran 1000 hari pertama kehidupan (Kemendesa PDTT, 2017).

Adapun bagian-bagian dari Intervensi Gizi Spesifik ialah intervensi dengan sasaran ibu hamil, intervensi dengan sasaran ibu menyusui dan anak usia 0-6 bulan, intervensi dengan sasaran ibu menyusui dan anak usia 7-23 bulan (Kemendesa PDTT, 2017).

Perencanaan dengan sasaran Ibu hamil, yaitu memberikan makanan tambahan pada ibu hamil untuk mengatasi kekurangan energi dan protein kronis, mengatasi kekurangan zat besi dan asam folat, mengatasi kekurangan iodium, menanggulangi kecacingan pada ibu hamil, melindungi ibu hamil dari malaria. Perencanaan dengan sasaran ibu menyusui dan anak usia 0-6 bulan, yaitu mendorong inisiasi menyusu dini (pemberisn ASI jolong/colostrum) dan mendorong pemberian ASI Ekslusif. Perencanaan dengan sasaran ibu menyusui dan anak usia 7-23 bulan, yaitu mendorong penerusan pemberian ASI hingga usia 23 bulan didampingi oleh pemberian MP-ASI, menyediakan obat cacing, menyediakan suplementasi zink, melakukan fotifikasi zat besi ke dalam makanan, memberikan perlindungan terhadap malaria, memberikan imunisasi lengkap, melakukan pencegahan dan pengobatan diare (Kemendesa PDTT, 2017).

Mitra (2015), mengkaji kebijakan penanggulangan kejadian stunting dan intervensi. Fokus Gerakan perbaikan gizi ditujukan kepada kelompok 1000 hari pertama kehidupan, pada tatanan global disebut Scaling Up Nutrition (SUN) dan di Indonesia disebut dengan Gerakan Nasional Sadar Gizi dalam Rangka Percepatan Perbaikan Gizi Pada 1000 Hari Pertama Kehidupan. Intervensi yang dilakukan terdiri dari intervensi spesifik (jangka pendek) dan intervensi sensitif (jangka panjang).

Sejalan dengan hasil penelitian ini, bahwa kegiatan "Rumah Belajar" sebagai bentuk Intervensi Gizi Sensitif akan memberikan dampak jangka panjang bagi balita dan keluarga. Pendidikan dapat membangun kesadaran pentingnya menerapkan pola hidup sehat dalam pengasuhan anak, termasuk pendidikan gizi keluarga dan masyarakat.

Kegiatan-kegiatan dalam Intervensi Gizi Sensitif antara lain memberikan pendidikan pengasuhan pada orang tua, memberikan pendidikan anak usia dini universal, memberikan pendidikan gizi masyarakat, memberikan edukasi kesehatan seksual dan reproduksi serta gizi pada remaja, menyediakan bantuan dan jaminan sosial bagi keluarga miskin, dan meningkatkan ketahanan pangan dan gizi (Sekretariat Wakil Presiden RI, 2017).

Pentingnya pendidikan pada keluarga juga dicermati oleh Mugianti (2018). Pengamatannya yang bertujuan menggambarkan faktor penyebab stunting pada anak stunting usia 25-60 bulan. Didapat faktor penyebab stunting, kurangnya pengetahuan keluarga tentang pemenuhan gizi dan terdapat orangtua dengan pendidikan rendah. Lebih lanjut Mugianti merekomendasi untuk petugas kesehatan UPTD Kesehatan Kecamatan Sukorejo melakukan penyuluhan tentang keluarga sadar gizi dan pemberian makanan tambahan selama 3 bulan pada balita dengan asupan energi dan protein rendah.

Pengamatan lain yang mendukung pentingnya peningkatan pengetahuan keluarga. Setiawan (2018) mencermati faktor-faktor yang berhubungan dengan kejadian stunting pada anak usia 24-59 bulan, dengan hasil uji chi-square 
menunjukkan terdapat hubungan yang bermakna antara tingkat asupan energi, riwayat durasi penyakit infeksi, berat badan lahir, tingkat pendidikan ibu dan tingkat pendapatan keluarga dengan kejadian stunting. Tingkat pendidikan ibu memiliki hubungan paling dominan dengan kejadian stunting. Lebih lanjut, Setiawan (2018), menyarankan pemerintah, instansi kesehatan, dan pihak terkait berkolaborasi memberikan masyarakat untuk mendapatkan pendidikan yang berkualitas, dalam memberikan asupan nutrien yang seimbang dan meningkatkan derajat kesehatan anak. Memberikan pemahaman yang benar tentang stunting. Bahwa stunting bukanlah karena keturunan, tapi suatu kondisi karena pemenuhan nutrisi yang tidak tepat.

Kondisi tubuh anak yang pendek seringkali dikatakan sebagai faktor keturunan (genetik) dari kedua orang tuanya, sehingga masyarakat banyak yang hanya menerima tanpa berbuat apa-apa untuk mencegahnya. Salah satu fokus pemerintah saat ini adalah pencegahan stunting. Upaya ini bertujuan agar anak-anak Indonesia dapat tumbuh dan berkembang secara optimal dan maksimal, dengan disertai kemampuan emosional, sosial, dan fisik yang siap untuk belajar, serta mampu berinovasi dan berkompetisi di tingkat global.

Stunting merupakan ancaman utama terhadap kualitas manusia Indonesia, juga ancaman terhadap kemampuan daya saing

\section{DAFTAR PUSTAKA}

Dinas Kesehatan Bali. (2018). Pemantauan Surveilans Gizi Tahun 2018. Denpasar.

Direktorat Gizi Masyarakat. (2017). Buku Saku Pemantauan Status Gizi (PSG) Tahun 2017. Jakarta: Direktorat Jendral Kesehatan Masyarakat Kementerian Kesehatan RI.

Hartono. (2017). Status Gizi Balita dan Interaksinya. Grobogan Jateng: Hanum Publisher.

Hurlock, B. Elizabeth. (2013). Perkembangan Anak. Jilid 1. Jakarta: Penerbit Erlangga.

Kemendesa PDTT. (2017). Buku Saku Desa dalam Penanganan Stunting. Jakarta.

Kementerian Kesehatan RI. (2017). Situasi Balita Pendek. Jakarta Selatan.

Kementerian Sosial RI. (2018). Modul Pengasuhan dan Pendidikan Anak. Jakarta.

Marimbi, H. (2010). Tumbuh kembang, status gizi dan imunisasi dasar pada balita. Yogyakarta: Nuha Medika, 26-7.

Mitra, M. (2015). Permasalahan Anak Pendek (Stunting) dan Intervensi untuk Mencegah bangsa. Hal ini dikarenakan anak stunted, bukan hanya terganggu pertumbuhan fisiknya (bertubuh pendek/kerdil) saja, melainkan juga terganggu perkembangan otaknya, yang mana tentu akan sangat mempengaruhi kemampuan dan prestasi di sekolah, produktivitas dan kreativitas di usia-usia produktif.

\section{SIMPULAN}

Ada perbedaan yang nyata dan signifikan pada kelompok perlakuan, tentang perilaku berisiko keluarga sebelum dan setelah kegiatan "Rumah Belajar". Pada kelompok kontrol tidak ada perbedaan yang nyata dan signifikan pada perilaku berisiko keluarga sebelum dan setelah kegiatan belajar dengan media pamflet.

Ada perbedaan rata-rata kelompok perlakuan yang mendapat kegiatan "Rumah Belajar" dengan kelompok kontrol yang mengikuti kegiatan belajar dengan media pamflet. Terdapat perbedaan yang bermakna pada perilaku berisiko keluarga, pada kelompok yang mendapat pengalaman mengikuti kegiatan "Rumah Belajar". Interaksi yang dibangun pada kegiatan "Rumah Belajar", mampu menggali kemampuan para keluarga untuk memahami factor-faktor yang dapat memicu kejadian stunting pada anak.
Terjadinya Stunting (Suatu Kajian Kepustakaan). Jurnal Kesehatan Komunitas, 2(6), 254-261. http://jurnal.htp.ac.id/index.php/keskom/art icle/download/85/69

Mugianti, S., Mulyadi, A., Anam, A. K., \& Najah, Z. L. (2018). Faktor Penyebab Anak Stunting Usia 25-60 Bulan di Kecamatan Sukorejo Kota Blitar. Jurnal Ners dan Kebidanan (Journal of Ners and Midwifery), 5(3), 268-278.Tersedia di http://jnk.phb.ac.id/index.php/jnk/article/d ownload/374/pdf

Ni'mah, K., \& Nadhiroh, S. R. (2016). Faktor yang berhubungan dengan kejadian stunting pada balita.Media Gizi Indonesia, 10(1), 13-19. https://ejournal.unair.ac.id/MGI/article/download/3 $117 / 2264$

Probohastuti, N. F., \& Rengga, A. (2019). IMPLEMENTATION OF NUTRITIONSENSITIVE INTERVENTIONS POLICY FOR STUNTING DECREASE IN 
BLORA REGENCY. Journal of Public Policy and Management Review, 8(4), 251-266.

https://ejournal3.undip.ac.id/index.php/jpp $\mathrm{mr} / \mathrm{article} / \mathrm{download} / 24936 / 22229$

Rifa'i A., Catharina Tri Anni. (2011). Psikologi Pendidikan. Semarang: UNNES Press.

Rosha, B. C., Sari, K., SP, I. Y., Amaliah, N., \& Utami, N. H. (2016). Peran intervensi gizi spesifik dan sensitif dalam perbaikan masalah gizi balita di Kota Bogor. Buletin Penelitian Kesehatan, 44(2), 127-138.

Sekretariat Wakil Presiden RI. (2017). 100 Kabupaten/kota prioritas untuk intervensi anak kerdil (stunting)'. p. 42 page. Jakarta.

Setiadi. (2013). Konsep dan Penulisan Riset Keperawatan. 2nd edn. Yogyakarta: Graha Ilmu.

Setiawan, E., Machmud, R., \& Masrul, M. (2018). Faktor-Faktor yang Berhubungan dengan Kejadian Stunting pada Anak Usia 24-59 Bulan di Wilayah Kerja Puskesmas Andalas Kecamatan Padang Timur Kota Padang Tahun 2018. Jurnal Kesehatan Andalas, 7(2), 275-284. http://jurnal.fk.unand.ac.id/index.php/jka/a rticle/view/813

Supariasa, I Dewa Nyoman, dkk. (2016). Penilaian Status Gizi Ed 2. Jakarta: EGC.

Widyaningsih, N. N., Kusnandar, K., \& Anantanyu, S. (2018). Keragaman pangan, pola asuh makan dan kejadian stunting pada balita usia 24-59 bulan. Jurnal Gizi Indonesia (The Indonesian Journal of Nutrition), 7(1), 22-29. https://ejournal.undip.ac.id/index.php/jgi/ar ticle/view/20025/14467 